\title{
Peran Buzzer Politik dalam Aktivitas Kampanye di Media Sosial Twitter
}

\author{
Felicia, Riris Loisa \\ Felicia.915150075@stu.untar.ac.id,Ririsl@fikom.untar.ac.id \\ Fakultas Ilmu Komunikasi Universitas Tarumanagara
}

\begin{abstract}
At first, the term of buzzer was only used to promote certain products with or without rewards, but since 2014 when the direct elections took place in Indonesia, politics began to use buzzer services. This study aims to determine the role of the political buzzer in political campaign activities on social media, especially Twitter and political buzzer activities. Some of the concepts that form the basis of this research are political communication in the form of political campaigns, new media, and social media. This type of research is descriptivequalitative using a qualitative approach. This study uses a case study research method. The subjects in this study were those who worked as buzzers on Twitter's with certain rewards, volunteer buzzers, and those who netted the public to join the buzzer. While the objects in this study are tweets written by voluntary buzzers and buzzers with certain rewards The conclusions in this study shows that buzzers with certain rewards play a role in expanding information through retweeting activities related to daily narratives and hashtags so that they can be seen by the public in the form of trending topics.
\end{abstract}

Keywords: Political Buzzer, Political Campaign, Twitter.

\begin{abstract}
Abstrak
Pada awalnya, istilah buzzer hanya digunakan untuk mempromosikan produk-produk tertentu dengan atau tanpa imbalan. Namun, sejak tahun 2014 saat pemilihan umum secara langsung terjadi di Indonesia, buzzer mulai memasuki dunia politik. Penelitian ini bertujuan untuk mengetahui peran buzzer politik dalam aktivitas kampanye politik di media sosial Twitter dan aktivitas buzzer politik. Beberapa konsep yang dijadikan landasan dalam penelitian ini adalah komunikasi politik dalam bentuk kampanye politik, new media, dan media sosial. Jenis penelitian ini adalah deskriptif-kualitatif dengan menggunakan pendekatan kualitatif. Penelitian ini menggunakan metode penelitian studi kasus. Subjek dalam penelitian ini adalah pihak yang bekerja sebagai buzzer di media sosial Twitter dengan imbalan tertentu, buzzer sukarelawan, serta pihak yang menjaring masyarakat untuk ikut tergabung menjadi buzzer. Sedangkan objek dalam penelitian ini adalah kicauan atau tweet yang dituliskan oleh buzzer sukarela maupun buzzer dengan imbalan tertentu. Kesimpulan dalam penelitian ini menunjukkan bahwa buzzer profesional atau buzzer dengan imbalan tertentu berperan untuk memperluas suatu informasi melalui aktivitas retweet terkait narasi dan hashtag harian hingga dapat dilihat oleh masyarakat dalam bentuk trending topic.
\end{abstract}

Kata Kunci: Buzzer Politik, Kampanye Politik, Twitter.

\section{Pendahuluan}

Kemajuan teknologi telah membawa berbagai perubahan dalam berbagai aspek kehidupan manusia. Salah satu perubahan yang amat jelas adalah hadirnya internet serta perkembangan teknologi hingga memunculkan media sosial. Berdasarkan hasil survei tahun 2017 yang dilakukan oleh Asosiasi Penyelenggara Jasa Internet 
Indonesia (APJII), sebanyak 143,26 juta jiwa dari total 262 juta penduduk di Indonesia menggunakan internet dan sebesar $87,13 \%$ digunakan untuk mengakses media sosial (APJII, 2017).

Keberadaan media sosial diawali dengan munculnya Facebook di tahun 2004 yang diikuti oleh Twitter di tahun 2006. Data dari kominfo.go.id menunjukkan bahwa pengguna Twitter di Indonesia mencapai angka 19,5 juta dari total 500 juta pengguna di seluruh dunia. (Kominfo, 2013).

Pengguna Twitter dapat mengelompokkan kicauan menurut topik atau jenis dengan menggunakan tagar (hashtag) kata atau frasa yang diawali dengan tanda '\#'. Sedangkan tanda '@', yang diikuti dengan nama pengguna, digunakan untuk mengirim atau membalas kicauan pada pengguna lain. Untuk memposting ulang kicauan pengguna lain dan membaginya pada pengikut sendiri, terdapat fitur retweet, yang dilambangkan dengan 'RT' (Abugaza, 2013).

Twitter adalah layanan jejaring sosial dan mikroblog yang memungkinkan penggunannya untuk mengirim dan membaca pesan berbasis teks hingga 140 karakter. Twitter didirikan pada bulan Maret 2006 oleh Jack Dorsey, Evan Williams, dan Biz Stone. Hingga bulan Januari 2013, terdapat lebih dari 500 juta pengguna terdaftar di Twitter, 200 juta diantaranya adalah pengguna aktif (Abugaza, 2013).

Hadirnya media sosial, seperti Twitter, tentu tidak luput dari berbagai istilah yang kemudian muncul di media sosial seperti netizen, followers, influencer, hingga buzzer. Buzzer berasal dari Bahasa Inggris yang berarti lonceng, bel, atau alarm sedangkan dalam Oxford Dictionaries, buzzer diartikan sebagai 'An electrical device that makes a buzzing noise and is used for signalling' yakni perangkat elektronik yang digunakan untuk membunyikan dengungan guna menyebarkan sinyal atau tanda tertentu.

Buzzer pada awalnya digunakan untuk mempromosikan suatu produk tertentu dengan atau tanpa imbalan tertentu. Namun, sejak tahun 2014, ketika pemilihan umum (pemilu) dilangsungkan di Indonesia, jasa buzzer mulai dilirik oleh aktoraktor politik. Dilansir dari Kumparan.com, profesi buzzer memiliki dua kategori yakni, buzzer yang dilakukan secara sukarela dan buzzer sesuai permintaan. Biasanya buzzer sesuai permintaan ini dilirik oleh para aktor politik seperti untuk memenangkan pilkada, pileg, hingga pilpres (KumparanNews, 2018).

Dalam konteks komunikasi, kampanye merupakan segala kegiatan yang bersifat membujuk. Intinya, di dalam kampanye terjadi serangkaian tindakan komunikasi yang ditujukan untuk membujuk sejumlah besar khalayak. Di sini terlihat bahwa untuk mencapai efek yang diharapkan, penting sekali untuk mengenal siapa khalayak, apa yang dinilai penting dan tidak penting oleh khalayak. Dengan kata lain perlu untuk menggali budaya dari khalayak yang akan dipersuasi (Loisa dan Setyanto, 2012).

Aktor-aktor politik mulai menggunakan jasa buzzer politik profesional untuk melakukan pendekatan terhadap masyarakat melalui pesan-pesan kampanye di media sosial.

Peran ini menjadi berbahaya jika dimanfaatkan untuk membentuk persepsi dan pandangan masyarakat akan kandidat politik tertentu, bahkan hingga membuat dan menyebarkan berita-berita hoax dan hatespeech antar lawan politik yang kemudian akan menimbulkan perpecahan di tengah masyarakat. Kata 'buzzer' pun lambat laun mulai dipandang masyarakat sebagai sebuah konotasi negatif, hal ini dapat muncul sebagai akibat dari kegiatan tidak bertanggung jawab buzzer politik profesional melalui media sosial. 
Aktivitas seorang buzzer politik hingga diusulkan menjadi sebuah profesi terlarang. Artikel di Kompas.com menuliskan bahwa, Presiden Republik Indonesia, Joko Widodo berjanji bahwa pemerintah akan berupaya melawan fitnah dan kebohongan yang ditebarkan para buzzer politik. Salah satunya dengan membentuk Badan Siber Nasional (Ihsanuddin dan Bohang, 2017).

Penelitian terdahulu mengenai 'Aktivisme Kelas Menengah Berbasis Media Sosial: Munculnya Relawan dalam Pemilu 2014' menunjukkan beberapa ciri-ciri buzzer sebagai berikut, membuat mini-story dan kultwit dengan bahasa teknokratis dan akademik, menggunakan akun anonim (sockpuppet), posting-an bersifat hit and run sehingga wacana dan isu bersifat temporer, dan wacana tersebut bersifat testing the water, untuk melihat aksi dan reaksi kelas menengah netizen (Jati, 2016).

Penelitian ini bertujuan untuk mengetahui proses dan aktivitas kerja seorang buzzer politik profesional terkait pelaksanaan tugas-tugas kampanye politik. Tugas dari twitter buzzer tidak terbatas hanya untuk mem-posting sebuah tweet saja, tetapi juga menjalankan campaign atau rangkaian informasi lebih lanjut kepada para follower. Jadi, tugas seorang twitter buzzer bisa menjadi layaknya brand ambassador, jadi seorang twitter buzzer juga harus benar-benar mengerti apa yang ia sebarkan ke dunia maya (Yuliahsaridwi, 2016).

Berbagai lika-liku buzzer politik dalam mengkampanyekan pesan politik tertentu kepada masyarakat tersebut mendorong peneliti untuk melakukan penelitian lebih dalam mengenai hal ini. Oleh karena itu, peneliti tertarik untuk melakukan penelitian yang berjudul 'Peran Buzzer Politik dalam Aktivitas Kampanye Politik di Media Sosial Twitter'.

\section{Metode Penelitian}

Metode yang digunakan dalam penelitian ini adalah kualitatif. Penelitian kualitatif bertujuan untuk menjelaskan fenomena dengan sedalam-dalamnya melalui pengumpulan data sedalam-dalamnya. Di sini yang lebih ditekankan adalah persoalan kedalaman (kualitas) data, bukan banyaknya (kuantitas) data (Kriyantono, 2012).

Jenis penelitian ini adalah deskriptif kualitatif. Menurut Bungin (2011) penelitian sosial menggunakan format deskriptif kualitatif bertujuan untuk menggambarkan, meringkaskan berbagai kondisi, berbagai situasi, atau berbagai fenomena realitas sosial yang ada di masyarakat yang menjadi objek penelitian, dan berupaya menarik realitas itu ke permukaan sebagai suatu ciri, karakter, sifat, model, tanda, atau gambaran tentang kondisi, situasi, ataupun fenomena tertentu. Peneliti menggunakan pendekatan kualitatif dalam penelitian ini karena selaras dengan pendekatan kualitatif, peneliti berusaha untuk mencari makna atau realitas dari sebuah fenomena yang akan diteliti. Penelitian ini lebih mengandalkan hasil konstruksi dan pemahaman setelah mengumpulkan data-data secara mendalam dari lapangan, berbeda dengan penelitian kuantitatif yang lebih bersifat terukur.

Penelitian ini menggunakan metode penelitian studi kasus. Menurut Bungin (2011) studi kasus ini merupakan studi yang mendalam hanya pada satu kelompok atau peristiwa. Peneliti ingin mencari sebuah informasi yang dapat diperoleh melalui kasus atau permasalahan yang dikaji. Fenomena munculnya buzzer di media sosial dalam melakukan aktivitas kampanye politik juga merupakan fenomena kontemporer yang dapat digali lebih dalam agar dapat menambah informasi bagi masyarakat. 
Pada penelitian ini, pengumpulan data dilakukan melalui studi pustaka, observasi, wawancara, dan penelusuran online. Teknik analisa data yang digunakan pada penelitian ini adalah tenik analisis data kualitatif model Strauss dan Corbin. Menurut Strauss dan Corbin analisis data kualitatif, terdiri atas tiga jenis pengodean (coding) utama, yaitu (1) pengodean terbuka (open coding), (2) pengodean berporos (axial coding), dan (3) pengodean selektif (selective coding) (Emzir, 2012). Peneliti menggunakan triangulasi dengan sumber data dan triangulasi dengan metode sebagai teknik keabsahan data pada penelitian ini.

\section{Hasil Temuan dan Diskusi}

Hasil temuan dalam penelitian ini akan peneliti tuliskan dalam beberapa subpembahasan:

Proses Keterlibatan Menjadi Buzzer Politik di Media Sosial

Terdapat dua kategori buzzer politik di media sosial yakni buzzer politik yang terlibat secara sukarela dan buzzer politik yang terlibat secara profesional. Proses keterlibatan menjadi seorang buzzer politik profesional di media sosial diawali dengan adanya open recruitment. Open recruitment ini secara sengaja ditujukan kepada mahasiswa-mahasiswi dengan tujuan agar dapat menggapai kaum milenial. Setelah tergabung menjadi buzzer politik melalui proses open recruitment, buzzerbuzzer politik tersebut akan di-briefing untuk melakukan tugas-tugas tertentu yang berhubungan dengan kampanye politik. Sedangkan proses keterlibatan seorang sukarelawan buzzer politik tidak diawali dengan open recruitment, melainkan buzzer-buzzer relawan tersebut telah terlebih dahulu membuat konten di media sosial Twitter yang selaras dengan ideologi pasangan calon tertentu dan kemudian dihubungi secara personal oleh tim kampanye pasangan calon tersebut, diminta untuk bergabung.

\section{Aktivitas Buzzer Politik di Media Sosial Twitter}

Aktivitas buzzer politik profesional dan relawan buzzer politik di media sosial Twitter memiliki beberapa perbedaan, meskipun tujuan utamanya tetap sama yakni untuk mengkampanyekan pasangan calon tertentu.

Buzzer politik profesional lebih banyak berperan secara pasif dalam menentukan pesan-pesan kampanye yang hendak ia sampaikan melalui akun-akun Twitter miliknya. Semua aktivitas buzzer politik profesional diatur dan dikoordinasi oleh pihak tertentu yang terhubung melalui grup Whatsapp. Pada awal tergabung menjadi buzzer politik profesional, mereka diminta untuk membuat masing-masing 10 akun di media sosial Facebook, Twitter, dan Instagram. Setiap akun tersebut harus diberikan identitas tertentu agar terlihat seperti akun sungguhan. Kemudian, melalui akun-akun tersebut buzzer-buzzer politik profesional ini akan menyalurkan pesan-pesan kampanye berupa narasi dan hashtag harian yang telah terlebih dahulu dikoordinasikan.

Akun-akun Twitter yang dibuat oleh buzzer politik profesional memiliki tugas masing-masing. Dari sepuluh akun Twitter, empat berperan untuk membela pasangan calon, empat untuk menyerang, dan dua berperan netral.

Buzzer politik dengan imbalan tertentu berperan untuk membuat sebuah narasi dan hashtag harian menjadi trending di media sosial sehingga akan banyak dilihat oleh masyarakat. Buzzer-buzzer ini berperan untuk memperluas suatu informasi hingga dapat dilihat oleh masyarakat dalam bentuk trending topic. Retweet terhadap 
pesan-pesan kampanye politik dapat bermacam-macam bentuknya, seperti program kerja, janji paslon kepada rakyat, data-data hasil survei, maupun kritik terhadap pasangan calon lain.

Berikut adalah beberapa contoh akun-akun buzzer yang telah diberikan identitas tertentu oleh buzzer politik.

Tabel 1. Hasil Observasi Akun Buzzer Politik di Media Sosial Twitter.

\begin{tabular}{|c|c|c|}
\hline No. & Akun Twitter & Analisis \\
\hline 1. & $@ \mathrm{RJ}$ & $\begin{array}{l}@ \mathrm{RJ} \text { adalah salah satu akun palsu yang dibuat oleh buzzer } \\
\text { 'B'. Dari observasi yang peneliti lakukan, akun Twitter @RJ } \\
\text { merupakan akun penggemar grup bola Liverpool. }\end{array}$ \\
\hline 2. & @IF & $\begin{array}{l}\text { Berdasarkan observasi peneliti, akun Twitter @IF merupakan } \\
\text { akun penggemar drama Korea. Hal ini dapat terlihat dari } \\
\text { huruf Korea dan \#goblin yang dituliskan pada biodata akun } \\
\text { ini. Selain itu, background pada akun ini juga merupakan } \\
\text { poster drama Korea Goblin. }\end{array}$ \\
\hline 3. & $@ \mathrm{RN}$ & $\begin{array}{l}\text { Akun @RN merupakan akun Twitter penggemar bola basket. } \\
\text { Hal ini dapat terlihat dari biodata yang dituliskan pada akun } \\
\text { ini yakni 'Basketball Enthusiast'. Selain itu, akun ini juga } \\
\text { memfollow atau mengikuti beberapa akun pemain bola basket } \\
\text { seperti akun milik Kobe Bryant. }\end{array}$ \\
\hline 4. & $@ D S$ & $\begin{array}{l}\text { @DS adalah akun yang diciptakan sebagai seorang } \\
\text { penggemar dunia fotografi. }\end{array}$ \\
\hline 5. & @ AG & $\begin{array}{l}\text { @ AG merupakan akun Twitter penggemar dunia kuliner. Hal } \\
\text { ini dapat terlihat dari akun yang diikuti seperti akun } \\
\text { @EaterNY dan @epicurious. Akun ini juga menuliskan 'big } \\
\text { appetite running in my blood' dan menggunakan foto koki } \\
\text { sebagai foto profil akun. }\end{array}$ \\
\hline
\end{tabular}

Sumber: Hasil Observasi Peneliti (2018)

Berdasarkan pengamatan peneliti kepada sepuluh akun yang dibuat oleh buzzer politik 'B', selama masa kampanye yakni 26 Desember 2017 hingga 8 Maret 2018 hampir setiap hari akun-akun ini me-retweet hashtag dan narasi yang dituliskan oleh akun juru bicara paslon, akun partai, ataupun akun resmi kampanye lainnya. Dalam satu hari, akun-akun ini bisa me-retweet kurang lebih 40 tweet dan saat malam debat kampanye akun-akun ini bisa menghasilkan tweet kurang lebih 55 tweet.

Saat debat kampanye berlangsung di televisi, buzzer-buzzer politik profesional akan berkumpul di basecamp, sebutan untuk tempat para buzzer politik berkumpul untuk menyaksikan bersama acara debat di televisi dan melakukan tugas-tugas buzzer politik seperti me-retweet pesan dukungan ataupun mendukung hasil survei.

Salah satu contoh pesan kampanye yang di-retweet oleh akun buzzer yang dibuat oleh buzzer 'B' adalah akun@DS. Akun @DS melakukan retweet-retweet terhadap pesan-pesan kampanye politik dan data-data hasil survei pada timeline akun Twitternya. Seperti tweet yang ia tuliskan semalam sebelum PILKADA 2017 yaitu 'bikin sejarah baru ah buat Jakarta hari ini. Gw \#CoblosX'. 
Gambar 1. Salah Satu Aktivitas Akun Buzzer Politik (@DS)

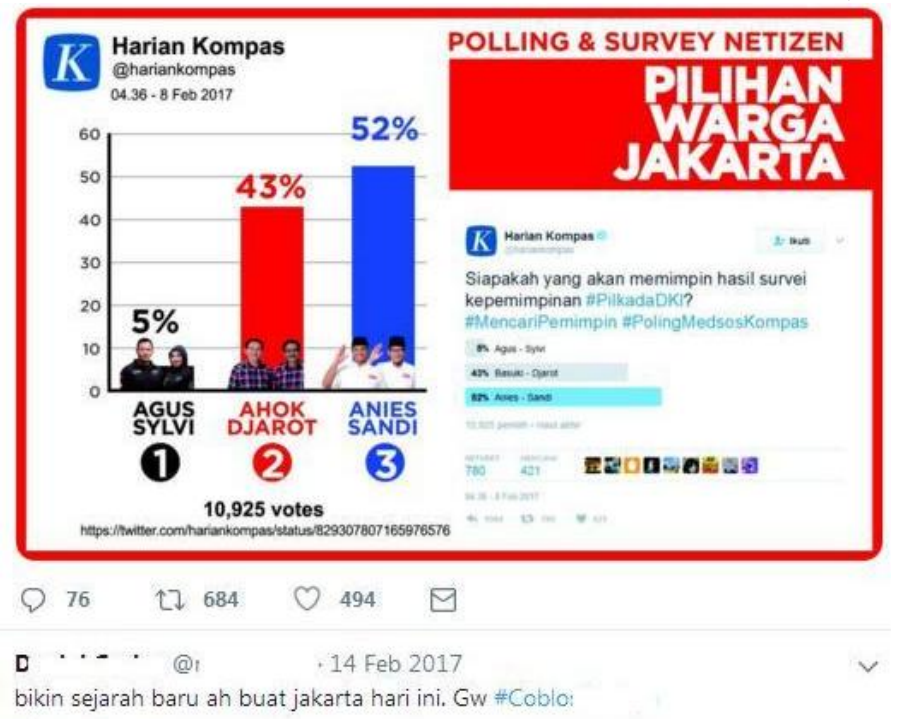

Sumber: Twitter.com

Masing-masing akun yang dibuat oleh buzzer politik profesional, dalam penelitian ini yang dimaksud adalah buzzer 'B', memiliki tugas dan perannya masing-masing, dengan proporsi pembagian empat akun untuk menyerang, empat akun untuk membela paslon, dan dua akun untuk netral. Bentuk kampanye negatif dengan pesan yang menyerang paslon lawan juga pernah dituliskan oleh salah satu akun buzzer yang dibuat oleh buzzer ' $\mathrm{B}$ '. Kampanye negatif itu dilakukan dengan memaparkan data mengenai paslon yang kemudian diretweet dengan menambahkan tweet 'yha sudah jelas mereka sudah sakit ati wkwk' pada tanggal 15 Februari 2017.

Gambar 2. Pesan Kampanye Negatif Akun Salah Satu Akun Buzzer Politik (@RN)

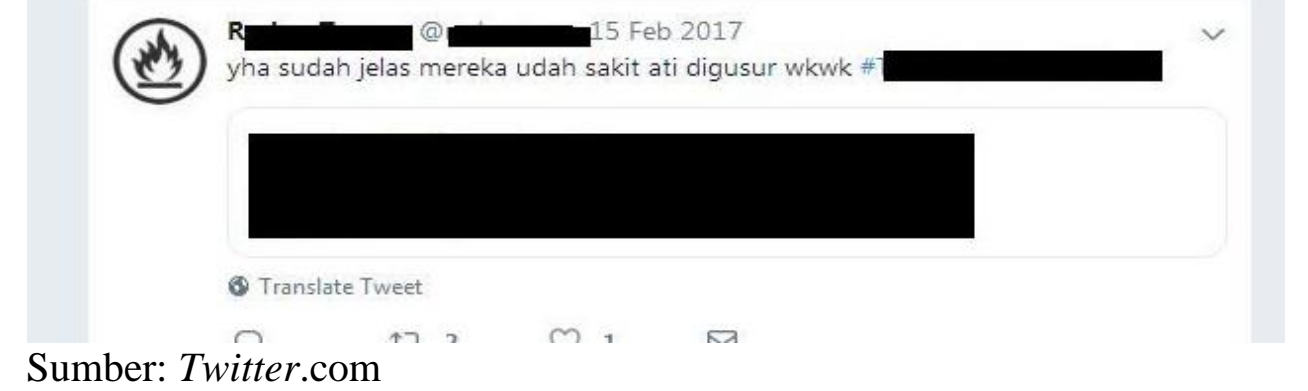

Sumber: Twitter.com

Hal yang kerap kali menjadi perhatian mengenai hadirnya buzzer politik di media sosial adalah pesan kampanye yang disampaikan kepada masyarakat. Hadirnya buzzer akan memberikan peluang kerja yang bagus, namun akhir-akhir ini, pesan kampanye yang disebarkan oleh buzzer politik cenderung merupakan kampanye negatif bukan kampanye positif. Berdasarkan hasil diskusi yang telah peneliti lakukan dengan seorang pengamat media sosial, Bapak Nukman Luthfie, hadirnya buzzer politik di media sosial merupakan hal yang sah-sah saja untuk dilakukan. Bahkan hadirnya profesi buzzer di media sosial merupakan lapangan kerja yang bagus untuk mengurangi angka pengangguran di Indonesia, asalkan pesan kampanye yang disampaikan bukan merupakan hoax. Model kampanye negatif memang diperbolehkan, tapi hal ini dikhawatirkan akan memunculkan berita-berita 
hoax dan memicu perselisihan. Hadirnya akun-akun anonim juga mempermudah akun tersebut bertindak provokatif.

Berbeda dengan buzzer politik profesional, buzzer relawan membuat sebuah akun anonim atas inisiatif diri mereka sendiri. Buzzer relawan berperan secara aktif dalam menyampaikan pesan kampanye sekaligus menyuarakan aspirasi mereka. Pesan kampanye dan hashtag yang dituliskan oleh buzzer-buzzer relawan di media sosial Twitter merupakan hasil dari diskusi bersama. Meskipun demikian, didalam tim yang terdiri dari buzzer-buzzer relawan, juga terdapat tim yang bekerja secara profesional dengan tujuan untuk mengiklankan paslon. Keselamatan pribadi merupakan salah satu alasan kuat yang mendorong para buzzer relawan politik untuk membuat akun anonim. Adanya kampanye hitam yang kerap kali menyerang paslon mendorong buzzer-buzzer relawan untuk membuat akun anonim tersebut. Akun-akun anonim yang telah dibuat oleh buzzer relawan tidak hanya digunakan untuk menyebarkan pesan kampanye positif seperti keberhasilan paslon namun juga kampanye negatif yakni kritik pada paslon lain.

\section{Simpulan}

Buzzer politik profesional di Indonesia terdiri dari buzzer relawan dan buzzer politik profesional yakni buzzer dengan imbalan tertentu. Buzzer politik di Indonesia memiliki proses perekrutan yang berbeda-beda. Buzzer politik profesional direkrut melalui proses open recruitment dan kemudian baru diminta untuk membuat akun akun untuk menyebarkan pesan kampanye tertentu. Sedangkan proses perekrutan buzzer relawan diawali dengan proses seleksi terhadap timeline Twitter yang dilihat sesuai dengan kriteria pendukung paslon.

Buzzer politik profesional di media sosial berperan untuk memperluas suatu informasi melalui aktivitas retweet terkait narasi dan hashtag harian hingga dapat dilihat oleh masyarakat dalam bentuk trending topic dan menjadi viral. Meskipun tidak sering dilakukan, namun terkadang buzzer politik profesional juga berperan untuk melakukan penyerangan melalui kritik terhadap pasangan calon atau aktor politik lain. Sedangkan, buzzer relawan politik di media sosial menyampaikan sebuah informasi di media sosial atas dasar inisiatif pribadi dilandaskan oleh kesamaan ideologi.

\section{Ucapan Terima Kasih}

Ucapan terima kasih peneliti berikan kepada semua narasumber yang telah bersedia untuk meluangkan waktunya dan memberikan informasi kepada peneliti selama proses pengumpulan data dalam penelitian ini. Peneliti juga ingin mengucapkan terima kasih kepada Fakultas Ilmu Komunikasi Universitas Tarumanagara.

\section{Daftar Pustaka}

Abugaza, Anwar. (2013). Social Media Politica: Gerak Massa Tanpa Lembaga. Tangerang: PT Tali Writing \& Publishing House.

Bungin, Burhan. (2011). Penelitian Kualitatif: Komunikasi, Ekonomi, Kebijakan Publik, dan Ilmu Sosial Lainnya. Jakarta: Kencana Prenada Media Group. 
Data Survei Asosiasi Penyelenggara Jasa Internet Indonesia (APJII). (2017). Infografis: Penetrasi \& Perilaku Pengguna Internet Indonesia. <file:///C:/Users/User/Downloads/x84Zf9ECHtnX6ogqp1W3VBSQFmukKJ $\% 20(1)$.pdf $>$, diunduh tanggal 6 September 2018

Emzir. (2012). Metodologi Penelitian Kualitatif: Analisis Data. Jakarta: PT Raja Grafindo Persada.

Ihsanuddin, \& Fatimah Kartini Bohang. (2017). "Buzzer” Politik Diusulkan Jadi Profesi Terlarang di Indonesia. 22 Februari 2017. <https://tekno.kompas.com/read/2017/02/22/15170807/.buzzer.politik.diusul kan.jadi.profesi.terlarang.di.indonesia>, diunduh tanggal 4 September 2018

Jati, W. (2016). Aktivisme Kelas Menengah Berbasis Media Sosial: Munculnya Relawan dalam Pemilu 2014. Jurnal Ilmu Sosial dan Ilmu Politik, 20(2), 147162. /*doi:http://dx.doi.org/10.22146/jsp.24795*/ doi:https://doi.org/10.22146/jsp.24795

Kominfo. (2013). Kominfo: Pengguna Internet di Indonesia 63 Juta Orang. 7 November 2013. <https://www.kominfo.go.id/content/detail/3415/kominfopengguna-internet-di-indonesia-63-juta-orang/0/berita_satker>, diunduh tanggal 2 September 2018.

Kriyantono, Rachmat. (2012). Teknik Praktis Riset Komunikasi. Jakarta: Kencana Pernada Media Group.

KumparanNews. (2018). Suburnya Buzzer dan Berkembangnya Bisnis Penggiringan Opini. $\quad 5 \quad$ September 2018. <https://kumparan.com/@kumparannews/suburnya-buzzer-dan berkembangnya-bisnis-penggiringan-opini-1536203838240146622>, diunduh tanggal 3 September 2018

Loisa, R., \& Setyanto, Y. (2012). Mencari Bentuk Kampanye Politik Khas Indonesia: Pencitraan Berbasis Dimensi Budaya. (Online). <http://komunikasi.unsoed.ac.id/sites/default/files/52.RIRISLOISA_tarumana gara.pdf $>$, diakses 29 Desember 2018

Yuliahsari, D. (2016). Pemanfaatan Twitter Buzzer Untuk Meningkatkan Partisipasi Pemilih Muda dalam Pemilihan Umum. Jurnal The Messenger, 7(1), 41-48. doi:http://dx.doi.org/10.26623/themessenger.v7i1.288

https://en.oxforddictionaries.com/definition/buzzer diakses tanggal 2 September 2018 